\title{
Monetary Policy Interest Rate Channel in Turkey: Toda-Yamamoto Method (2011-2018)
}

\section{Leyla BASTA $V^{1}$}

Türkiye'de Para Politikasının Faiz Kanalı: Toda-Yamamoto Metodu 2011-2018

\section{ARTICLE INFO}

Article History:

Date Submitted: 14.02.2020

Date Accepted: 16.05.2020

JEL Classification:

$\mathrm{E} 52$,

E43,

C32.

Keywords:

Monetary Transmission

Mechanism,

Interest Rate Channel,

Granger Causality Test,

Toda-Yamamoto

Method.

\section{ABSTRACT}

This study analyzes the channel through which monetary policy has affected real economic activity in Turkey during 2011Q1-2018Q2. There is a novel monetary policy stance of the Turkish Central Bank (TCMB) from 2011 on, following the initiation of explicit inflation targeting in 2006. Within the framework financial stability is added to previous target of price stability and diversified interest rates and liquidity measures have been introduced as new tools along with classical short-term interest rate. Existence of interest channel has been tested by two causality methods, namely: Granger and Toda-Yamamoto. Results imply that interest channel is not operative in Turkey in the traditional and/or New Keynesian sense, but rather higher demand leads to higher prices (and vice versa) affecting interest rates in return. Findings do not comply with findings of the previous periods' studies that interest rate channel is effective in Turkey.

\footnotetext{
${ }^{1}$ BDDK / Retired Senior Banking Specialist, bastav06@yahoo.com.tr, bastavl@bilkent.edu.tr
} 


\section{Introduction:}

Turkey has adopted an exchange rate based stabilization program by 1999, involving the crawling peg regime, which has been interrupted with the financial crises of 2001. In the aftermath of the crises exchange rates were left to float freely and "implicit inflation targeting" was adopted. The new regime involved announcing an inflation target, using short term interest rates to reach this target, and keeping "monetary base" within certain limits as additional nominal anchor. This transitional phase of the new regime between 2002-2005 has reached its goal in controlling inflation, under management and responsibility of the Central Bank, keeping it below two digit levels from 2004 on.

After achieving stability over 2001 crises and acquiring control over macroeconomic indicators Turkey has passed on to "explicit inflation targeting" from 2006 on, where inflation targets were announced annually within a certain band, and short term rates were used as main policy tool to reach targeted levels. During the regime Central Bank incurred difficulties in hitting targets out of various reasons like oil prices, international capital flows, agricultural price fluctuations etc. To top it all, 2008 financial crises deteriorated the macroeconomic aggregates raising the need to acquire a new policy stance. From 2011 on financial stability was set as additional monetary policy target along with price stability. Within the new framework, short term interest rates remained as the main policy tool, with interest rate corridor adopted to control for movements of capital inflows as well as introduction of additional liquidity measures like required reserves and reserve intervention mechanism. Although Central Bank aimed to bring in flexible system to maintain stability, use of multiple rates caused confusion in market agents which might have diverted or blurred the signalling effects interrupting with effectiveness of the interest channel (Özatay, 2011)

From June 2018 on TCMB has announced new measures to simplify monetary policy and overcome the confusion caused in market actors by multiple policy rates treatment. Accordingly policy rate has been announced as the weekly repo rate (instead of the previous late liquidity window rate used since november 2017) and overnight borrowing and lending rates have been announced 150 basis points above/below the policy rate. Annulation of late liquidity and direct treatment of weekly repo as the policy rate is expected to strengthen interest 
rate channel and raise effectiveness of the monetary policy (Press Statement of the TCMB, 2018-21). During the year new policy stance was also supported by foreign exchange liquidity measures to avoid fluctuations in TL.

Traditional Keynesian hypothesis postulates that interest rate is the important policy tool in triggering higher expenditures with rising levels of production and income. Valid within the Hicksian IS-LM framework, the hypothesis sees that money supply (M) increases (declines) will cause interest rate (i) declines (hikes), in return for which investment (I) and income (Y) will both rise (fall) (see Section: 2) At the presence of price rigidity, higher (lower) real balances will lead to increasing (decreasing) level of economic activity (Mishkin, 2004). This basic mechanism forms essence of the interest rate channel of monetary policy still in our day. Within the New Keynesian "New Consensus" approach, interest rate is the essential policy instrument (determined as per Taylor's Rule), which will affect real expenditures by the abovementioned mechanism and provide the inflation rate envisaged by inflation targeting. In this approach money is created rather endogeneously by economic agents.

In this paper, we analyze whether the Keynesian interest channel has been operative in Turkey during the exceptional inflation targeting period of 2011-2018. Causality between variables is examined via Toda-Yamamoto method, against which Granger test results are compared. The theoretical background is followed by a presentation of selected empirical studies on the subject. Data analysis and unit root tests are followed by causality results. Evaluation and conclusions conclude the study.

\section{Interest Rate Channel of the Monetary Transmisson Mechanism}

Monetary transmission is the mechanisms and the dynamics through which monetary policy changes affect income of the economy. Mechanisms are mainly expressed under three titles which are: 1) Interest rate (or the money view), 2) Credit and, 2) Other asset prices channels (Mishkin, 2004; Miskin, 1995).

According to the traditional Keynesian interest rate channel, rise in money supply (M) will lower nominal interest $\left(\mathrm{i}_{\mathrm{n}}\right)$ and real interest rates $\left(\mathrm{i}_{\mathrm{r}}\right)$, raising investments $(\mathrm{I})$ and thereby national income (Y). (Keyder and Ertunga, 2012; Mishkin, 2004; Miskin, 1995). 


$$
\mathrm{M} \uparrow \rightarrow \mathrm{i}_{\mathrm{n}} \downarrow \rightarrow \mathrm{i}_{\mathrm{r}} \downarrow \rightarrow \mathrm{I} \uparrow \rightarrow \mathrm{Y} \uparrow
$$

The basic assumption of sticky prices enables real interest rates to fall. After a fall of $i_{n}$ by monetary expansion, prices adjust only gradually, enabling a decline in the $\mathrm{i}_{\mathrm{r}}$ even for some temporary time. The fall in $\mathrm{i}_{\mathrm{r}}$ will bring in a rise in investments contributing to higher national income $Y{ }^{2}$ Whenever prices are very flexible and are often revised by changes in economic signals, interest channel will be less effective. This is why the channel works no good in high inflation countries, during high inflation periods (Mishkin, 2004; Peersman, 2001; Bernanke and Gertler, 1995; Hubbard, 1995; Mishkin, 1995; Taylor 1995). Initial emphasis of Keynes was on the effect of (i) on (I) via the business fixed investment decisions; however, later it was observed that effect of interest rates on investment spending was not limited to business fixed investments and consumers' purchases of housing and consumer durable expenditures also came to be regarded as investment (Mishkin 2004; Mishkin, 1995; Taylor, 1995; Bernanke and Gertler, 1995).

For interest channel to be effective, it is necessary that interest elasticity of money demand be low and interest elasticity of investment function be high. Unless there is a liquidity trap, money supply will affect interest rates and investment volume via changing expectations, and thereby real economic activity. Higher interest rate elasticity of investments will help boost/curb the economic activity stronger and effects on the real economy will be higher (Miskin, 2004; Keyder and Ertunga, 2012).

Within the New Keynesian "New Consensus" framework (Weber, 2006; Arestis and Sawyer, 2003; Woodford, 2003), interest rate is the essential policy instrument, within the inflation targeting regime, which will affect real expenditures by changing the nominal and real

\footnotetext{
${ }^{2}$ Investment decision of business owners and consumers depend on the long term real interest rates. The fall in real short term rates enabled by sticky prices will lead to declines in long term real interest (which is the average of expected future short term real rates) which will raise income. Since the fall in long term rates is contingent upon change in expectations of economic agents, final effect on income involves uncertainty (Mishkin, 2004; Peersman 2001; Mishkin 1995).
} 
rates as described above. Interest rate is determined by the central bank according to the amount of deviation of output and inflation from their long-term trend values. Contrary to the traditional Keynesian approach where money supply is determined exogeneously by the Central Bank, New Consensus postulates that money supply is created endogenously by the real sector activities of economic agents demanding credits from the banking sector, in return for which banks create deposits. Here banks' role is vital vis a vis their neglect in the traditional Keynesian view.

\section{Previous Research}

Table: 1 Empirical Research on Interest Rate Channel

\begin{tabular}{|c|c|c|c|}
\hline Author(s) & $\begin{array}{l}\text { Countries } \\
\text { and Period }\end{array}$ & Method & Results \\
\hline $\begin{array}{l}\text { Butzen et.al. } \\
\qquad(2001)\end{array}$ & $\begin{array}{c}\text { Belgium } \\
(1985-1998)\end{array}$ & $\begin{array}{l}\text { Panel Data } \\
\text { Analysis }\end{array}$ & $\begin{array}{l}\text { Interest channel effective for firms in } \\
\text { Belgium, especially for small scale and } \\
\text { capital intensive ones. }\end{array}$ \\
\hline $\begin{array}{c}\text { Peersman } \\
\text { (2001) }\end{array}$ & $\begin{array}{c}\text { Euro Area } \\
(1980-1998)\end{array}$ & VAR Analysis & $\begin{array}{l}\text { Effective interest channel than other } \\
\text { transmission channels, especially in capital } \\
\text { intensive and durable consumer goods } \\
\text { sectors }\end{array}$ \\
\hline Sellon (2002) & $\begin{array}{l}\text { US (1972- } \\
\text { 2000) }\end{array}$ & $\begin{array}{l}\text { Graphical, } \\
\text { Statistical } \\
\text { Analysis }\end{array}$ & $\begin{array}{l}\text { Deregulation, financial innovation, } \\
\text { transparent monetary policy has increased } \\
\text { effectiveness of interest rate channel }\end{array}$ \\
\hline Reyes (2002) & $\begin{array}{c}\text { US } \\
(1972-2000)\end{array}$ & VAR Analysis & $\begin{array}{l}\text { Interest rate channel is effective in the US, } \\
\text { as well as real expenditures, assets prices, } \\
\text { money }\end{array}$ \\
\hline
\end{tabular}




\begin{tabular}{|c|c|c|c|}
\hline $\begin{array}{l}\text { Chirink, R.S., } \\
\text { Kalckreuth } \\
\text { (2003) }\end{array}$ & $\begin{array}{c}\text { Germany } \\
(1988-1997)\end{array}$ & $\begin{array}{l}\text { ADL Models } \\
\text { With GMM }\end{array}$ & $\begin{array}{l}\text { Interest rate channel effective in } \\
\text { investment decisions, creditworthiness of } \\
\text { firm plays part too }\end{array}$ \\
\hline $\begin{array}{l}\text { Berument and } \\
\text { Froyen (2006) }\end{array}$ & $\begin{array}{c}\text { US } \\
(1975-2002)\end{array}$ & $\begin{array}{l}\text { VAR } \\
\text { Analysis }\end{array}$ & $\begin{array}{l}\text { FED funds rate shocks affect tl interest } \\
\text { rates, but smaller and less persistent in the } \\
\text { post } 1979 \text { period }\end{array}$ \\
\hline $\begin{array}{l}\text { Bhuiyan and } \\
\text { Lucas (2007) }\end{array}$ & $\begin{array}{c}\text { Canada } \\
(1980-2002)\end{array}$ & $\begin{array}{l}\text { Recursive } \\
\text { VAR Model }\end{array}$ & $\begin{array}{l}\text { Interest and fx channel are effective in } \\
\text { monetary transmission mechanism }\end{array}$ \\
\hline $\begin{array}{l}\text { Yue and Zhou } \\
\text { (2007) }\end{array}$ & $\begin{array}{l}\text { China (1996- } \\
\text { 2005) }\end{array}$ & $\begin{array}{l}\text { Granger } \\
\text { Causality }\end{array}$ & $\begin{array}{l}\text { No Causality Between C, I and interest } \\
\text { rates due to lack of competitive markets }\end{array}$ \\
\hline Mehrotra(2007) & $\begin{array}{l}\text { Japan, Hong } \\
\text { Kong, China }\end{array}$ & $\begin{array}{c}\text { SVAR } \\
(1991-2004)\end{array}$ & $\begin{array}{l}\text { Important interest, fx rate channels in } \\
\text { Japan, Hong Kong, ineffective in China. }\end{array}$ \\
\hline Demary (2010) & $\begin{array}{l}10 \text { OECD } \\
\text { Countries }\end{array}$ & $\begin{array}{l}\text { VAR Analysis } \\
(1970-2005)\end{array}$ & Rise in interest rate leads to falling output. \\
\hline \multicolumn{4}{|c|}{ Studies on Turkey } \\
\hline İnal (2006) & $(2001-2006)$ & $\begin{array}{l}\text { Regression } \\
\text { Analysis }\end{array}$ & $\begin{array}{l}\text { Post } 2001 \text { crises policies, more effective } \\
\text { interest channel, effective on long term } \\
\text { interest rates }\end{array}$ \\
\hline $\begin{array}{l}\text { Başçı } \\
\text { et al. (2007) }\end{array}$ & $(1990-2006)$ & $\begin{array}{l}\text { Statistical, } \\
\text { Graphical, } \\
\text { Qualitative } \\
\text { Analysis }\end{array}$ & $\begin{array}{l}\text { Post } 2001 \text { crises, interest rate channel has } \\
\text { become more operative }\end{array}$ \\
\hline
\end{tabular}




\begin{tabular}{|c|c|c|c|}
\hline $\begin{array}{l}\text { Kara et al. } \\
\text { (2007) }\end{array}$ & (1989-2005) & $\begin{array}{c}\text { Kalman Filter } \\
\text { Approach }\end{array}$ & $\begin{array}{c}\text { Rise in interest rates causes an output } \\
\text { deficit }\end{array}$ \\
\hline $\begin{array}{c}\text { Aktaş et.al. } \\
\text { (2009) }\end{array}$ & $(2004-2008)$ & $\begin{array}{l}\text { Regression } \\
\text { Analysis }\end{array}$ & $\begin{array}{l}\text { Interest rate changes effect GDP, via long- } \\
\text { term interest rates' effects on investments }\end{array}$ \\
\hline $\begin{array}{l}\text { Büyükakın } \\
\text { et.al. (2009) }\end{array}$ & $(1990-2007)$ & $\begin{array}{l}\text { Causality } \\
\text { Tests }\end{array}$ & $\begin{array}{l}\text { Interest rate changes affect investment, } \\
\text { prices and GDP by order }\end{array}$ \\
\hline $\begin{array}{l}\text { Erdoğan and } \\
\text { Yildırım (2010) }\end{array}$ & $(1995-2008)$ & VAR Analysis & $\begin{array}{l}\text { Interest channel did not work before 2002, } \\
\text { effective post } 2002\end{array}$ \\
\hline $\begin{array}{c}\text { Saraç and Uçan } \\
\text { (2013) }\end{array}$ & $(1990-2011)$ & $\begin{array}{c}\text { Kalman Filter } \\
\text { Approach }\end{array}$ & $\begin{array}{c}\text { Post } 2002 \text { interest rate channel } \\
\text { effectiveness rises }\end{array}$ \\
\hline
\end{tabular}

There are many studies on the monetary policy but far less in number on the interest rate channel uniquely, for various countries. Results majorly reveal that interest rate channel is effective in the US, european countries and Canada during the 1980s and 1990s as well as in east asia like Japan and Hong Kong, with the exception of China. Interest channel has also been operative in Turkey during the 1990s and 2000s, getting more effective during post 2001 under structural adjustment program and inflation targeting regime. Most recent empirical studies have been included in the survey.

\section{Data and the Model}

The data used in this study is comprised of weighted average interest rate (i), (central bank's weighted average of the overnight lending rate plus its weekly repo rate), industrial production index (ind), gross domestic product (Y), fixed capital investment (I), and consumer price index (cpi). Gross domestic product is the chained index of the expenditure series with 
2009 base year, fixed capital investment is the industrial production index brought to 2009 base year, inflation is monthly percentage rate, as well as the interest rate in percentages. Data is of monthly frequency, series are deseasonalized by Tramo/Seats and (I) and (Y) are intrapolated from quarterly. (i) and (ind) are obtained from TCMB website, whereas (I), (Y) and (cpi) are from the Turkish Institute of Statistics (TÜIK) database. Data handling and causality analysis is realized by EViews 9 program.

\subsection{Unit Root Tests}

Following unit root tests of the time series, Granger causality and Toda-Yamamoto methods are used to analyze causality between the variables.

Table 1: Unit Root Test Results

\begin{tabular}{|l|c|c|c|c|c|c|}
\hline \multirow{2}{*}{ Variables } & \multicolumn{4}{|c|}{ Test Statistic Values (with constant and trend) } \\
\cline { 2 - 7 } & \multicolumn{2}{|c|}{ ADF } & \multicolumn{2}{c|}{ PP } & \multicolumn{2}{c|}{ KPSS } \\
\hline & $I(0)$ & $I(1)$ & $I(0)$ & $I(1)$ & $I(0)$ & $I(1)$ \\
\hline (i) interest rate & -1.14 & $-8.30^{*}$ & -1.37 & $-8.31^{*}$ & 0.15 & $0.07^{*}$ \\
\hline (I) fixed capital investment & $-3.52^{*}$ & & $-7.77^{*}$ & & $0.11^{*}$ & \\
\hline (ind) industrial prod index & -3.15 & $-16.00^{*}$ & $-5.43^{*}$ & & $0.12^{*}$ & \\
\hline (cpi) inflation & & & & & & \\
\hline
\end{tabular}

Schwarz Info criterion is used to choose the lag length of ADF test whereas Bartlett Kernal spectral estimation method with Newey-West bandwidth is used for the PP test. KPSS tests null hypothesis of stationarity. " and ** denote stationary series at the $5 \%$ and $1 \%$ level of significance, respectively. 
In the table above interest rate (i) is I(1), investment (I) and inflation (cpi) are I(0) by all three tests, industrial production index (ind) is $\mathrm{I}(0)$ by Phillips Perron and KwiatkowskiPhillips-Schmidt-Shin whereas (Y) is I(0) by the ADF as well as KPSS. Since the four variables are of different levels of integration ${ }^{3}$, we do not apply the usual VAR, but test for causality via Toda-Yamamoto (TY) (1995) method. TY enables analyzing causality between the time series without any prerequisites about stationarity and cointegration (Dritsaki, 2017; Alimi and Ofonyelu, 2013; Toda and Yamamoto, 1995), Results of the TY test are in turn compared with those of Granger causality.

\subsection{Causality Analysis and Results}

VAR model is useful for specifying direction of causality between the variables which is especially important in the conduct of monetary policy by central banks. VAR modeling also enables measuring direction and longitude of monetary policy shocks' effects on economic variables. However VAR requires stationarity of the time series in the system. We test causality between the variables with TY method primarily for simple Granger test is criticized on the points specified below. Simple Granger test is nonetheless applied by differencing the only I(1) variable (i) to compare and contrast against the TY results (Dritsaki, 2017; Alimi and Ofonyelu, 2013).

i) Granger causality may be subject to specification bias in case of omitted variables and/or due to number of lagged variables in the system.

ii) Simple Granger testing can give spurious results on the functions with non-stationary variables

iii) Use of F test will not be healthy with integrated variables (Gujarati, 2006).

iv) Error Correction by Engle and Granger (1987), VAR by Johansen and Juselius (1990) and Johansen (1991) for testing causality maybe cumbersome.

v) Precision of Granger causality with the EC is further criticized (Dritsaki, 2017) in case of dependence between the parameters.

\footnotetext{
${ }^{3}$ Interest rate is $\mathrm{I}(1)$ with the Zivot Andrews unit root test with structural break, whereas industrial production is $\mathrm{I}(0)$.
} 
Addressing abovementioned deficiencies of the Granger causality, Toda and Yamamoto (1995) have offered a method of augmented VAR providing asymptotic distribution of the Wald statistic, which is robust independent of the level of integration and cointegration of the variables in the system. At the first step we find order of integration of each time series, getting the maximum order $\left(\mathrm{d}_{\max }\right)$ whenever order of integration is different. Following, a VAR of order $\mathrm{k}^{4}$ at the series level is estimated regardless of level of integration of the variables. At the third step augmented VAR with $\left(\mathrm{k}+\mathrm{d}_{\max }\right)$ order is estimated where; the Granger non-causality tests are applied, with block exogeneity Wald statistics with $\mathrm{X}^{2}$ distribution.

\subsubsection{Causality with the Industrial Production Index}

Table 2: Toda-Yamamoto No-Causality Test Four Variable VAR Model Results (i, I, ind, cpi)

\begin{tabular}{|c|c|c|c|c|c|}
\hline $\begin{array}{l}\text { Dependent } \\
\text { Variable }\end{array}$ & $\operatorname{Lag}(k)$ & $\operatorname{Lag}\left(k+d_{\max }\right)$ & Chi-sq & Prob. & $\begin{array}{c}\text { Direction of } \\
\text { Causality }\end{array}$ \\
\hline \multicolumn{6}{|c|}{ (i) interest rate } \\
\hline I & 2 & $2+1$ & 0.84 & 0.66 & $\mathrm{I} \neq>\mathrm{i}$ \\
\hline ind & 2 & $2+1$ & 0.97 & 0.62 & ind $\neq>\mathrm{i}$ \\
\hline сpi & 2 & $2+1$ & 15.95 & $3 e-4$ & сpi $\rightarrow \mathbf{i}$ \\
\hline \multicolumn{6}{|c|}{$\begin{array}{l}\text { (I) fixed capital } \\
\text { investment }\end{array}$} \\
\hline $\mathrm{i}$ & 2 & $2+1$ & 1.91 & 0.38 & $\mathrm{i} \neq>\mathrm{I}$ \\
\hline ind & 2 & $2+1$ & 11.67 & $3 e-3$ & ind $\rightarrow$ I \\
\hline срі & 2 & $2+1$ & 5.02 & 0.08 & cpi $\neq>$ I \\
\hline \multicolumn{6}{|c|}{$\begin{array}{l}\text { (ind) industrial } \\
\text { prod index }\end{array}$} \\
\hline $\mathrm{i}$ & 2 & $2+1$ & 1.04 & 0.60 & $i \neq>$ ind \\
\hline I & 2 & $2+1$ & 3.53 & 0.17 & $\mathrm{I} \neq>$ ind \\
\hline сpi & 2 & $2+1$ & 3.27 & 0.19 & cpi $\neq>$ ind \\
\hline
\end{tabular}

\footnotetext{
${ }^{4} \mathrm{k}$ is found out by optimum lag selection with one of the AIC, SC or HQ criteria in the VAR model.
} 


\begin{tabular}{|c|c|c|c|c|c|}
\hline (cpi) inflation & & & & & \\
\hline $\mathrm{i}$ & 2 & $2+1$ & 3.33 & 0.19 & $\mathrm{i} \neq>$ cpi \\
\hline $\mathrm{I}$ & 2 & $2+1$ & 7.81 & 0.02 & $\mathbf{I} \rightarrow \mathbf{c p i}$ \\
\hline ind & 2 & $2+1$ & 0.16 & 0.92 & ind $\neq>$ cpi \\
\hline
\end{tabular}

Table 3: Simple Granger Causality Test Results (i, I, ind, cpi)

\begin{tabular}{|c|c|c|c|}
\hline $\begin{array}{c}\mathrm{H}_{0} \text { (causality does } \\
\text { not exist) }\end{array}$ & F statistic & Prob. & $\begin{array}{l}\text { Direction of } \\
\text { Causality }\end{array}$ \\
\hline \multicolumn{4}{|l|}{ d(i) interest rate } \\
\hline from $\mathrm{I}$ to $\mathrm{i}$ & 2.41 & 0.10 & $\mathrm{I} \neq>\mathrm{i}$ \\
\hline from ind to i & 2.83 & 0.06 & ind $\neq>\mathrm{i}$ \\
\hline from cpi to i & 7.82 & $8 \mathrm{e}-4$ & сpi $\rightarrow \mathbf{i}$ \\
\hline \multicolumn{4}{|l|}{$\begin{array}{l}\text { (I) fixed capital } \\
\text { investment }\end{array}$} \\
\hline from $\mathrm{i}$ to $\mathrm{I}$ & 0.73 & 0.49 & $i \neq>I$ \\
\hline from ind to I & 7.65 & $9 \mathrm{e}-4$ & ind $\rightarrow I$ \\
\hline from cpi to I & 1.77 & 0.18 & cpi $\neq>$ I \\
\hline \multicolumn{4}{|l|}{$\begin{array}{l}\text { (ind) industrial } \\
\text { prod index }\end{array}$} \\
\hline from $i$ to ind & 0.48 & 0.62 & $i \neq>$ ind \\
\hline from I to ind & 3.98 & 0.02 & $I \rightarrow$ ind \\
\hline from cpi to ind & 1.12 & 0.33 & cpi $\neq>$ ind \\
\hline \multicolumn{4}{|l|}{ (cpi) inflation } \\
\hline from i to cpi & 4.07 & 0.02 & $\mathbf{i} \rightarrow \mathbf{c p i}$ \\
\hline from I to cpi & 1.91 & 0.16 & $I \neq>$ cpi \\
\hline from ind to cpi & 2.14 & 0.12 & ind $\neq>$ cpi \\
\hline
\end{tabular}


Test results are evaluated for 5\% level of significance. Results of the Toda-Yamamoto Methodology reveal that there is no causality running from interest rate towards the real economy aggregates investment and income as assumed by Keynesian channel. Interestingly, causality runs in reverse order just from investment to cpi and from cpi to the interest rate directly. Industrial production also effects cpi indirectly via investments. There is also direct effect of industrial production on the investment. On the other hand results of simple Granger test reveal two way causality at the five percent significance level between cpi inflation and interest rate as well as between industrial production and investment. Results together imply causality running from real economic activity, investments to inflation, and then from inflation towards the interest rates. It can be stated that interest rate during the 2011-2018 period of inflation targeting regime has not been pro-active policy tool and has not succeeded in shaping expectations of economic agents. Rather industrial production and investment expenditures of real economic agents have determined the level of real economic activity, which in turn have raised prices, causing monetary authorities to follow suit and change level of interest rates to adjust for demand and inflationary pressures.

Figure 1: Toda Yamamoto

$$
\text { ind } \rightarrow \mathrm{I} \rightarrow \mathrm{cpi} \rightarrow \mathrm{i}
$$

\section{Figure 2: Simple Granger Causality}

$$
\begin{aligned}
& \text { cpi } \leftrightarrow \text { i } \\
& \text { ind } \leftrightarrow \text { I }
\end{aligned}
$$

\subsubsection{Causality with the GDP}

Causality analysis is redone, at $5 \%$ level of significance, this time with the interest rate (i), fixed capital investment (I), consumer price index (cpi) and gross domestic product (Y). 
Table 4: Toda-Yamamoto No Causality Test Four Variable VAR Model Results (i, I, Y, cpi)

\begin{tabular}{|c|c|c|c|c|c|}
\hline $\begin{array}{l}\text { Dependent } \\
\text { Variable }\end{array}$ & $\operatorname{Lag}(\mathbf{k})$ & $\operatorname{Lag}\left(k+d_{\max }\right)$ & Chi-sq & Prob. & $\begin{array}{c}\text { Direction of } \\
\text { Causality }\end{array}$ \\
\hline \multicolumn{6}{|c|}{ (i) interest rate } \\
\hline I & 2 & $2+1$ & 0.48 & 0.79 & $\mathrm{I} \neq>\mathrm{i}$ \\
\hline $\mathrm{Y}$ & 2 & $2+1$ & 0.69 & 0.71 & $Y \neq>i$ \\
\hline cpi & 2 & $2+1$ & 16.35 & $3 e-4$ & cpi $\rightarrow \mathbf{i}$ \\
\hline \multicolumn{6}{|c|}{$\begin{array}{l}\text { (I) fixed capital } \\
\text { investment }\end{array}$} \\
\hline $\mathrm{i}$ & 2 & $2+1$ & 2.13 & 0.34 & $i \neq>I$ \\
\hline Y & 2 & $2+1$ & 7.55 & 0.02 & $\mathbf{Y} \rightarrow \mathbf{I}$ \\
\hline cpi & 2 & $2+1$ & 2.62 & 0.27 & cpi $\neq>$ I \\
\hline \multicolumn{6}{|l|}{$(Y)$ income } \\
\hline $\mathrm{i}$ & 2 & $2+1$ & 2.85 & 0.24 & $\mathrm{i} \neq>\mathrm{Y}$ \\
\hline I & 2 & $2+1$ & 1.06 & 0.59 & $\mathrm{I} \neq>\mathrm{Y}$ \\
\hline cpi & 2 & $2+1$ & 7.79 & 0.02 & cpi $\rightarrow \mathbf{Y}$ \\
\hline \multicolumn{6}{|c|}{ (cpi) inflation } \\
\hline $\mathrm{i}$ & 2 & $2+1$ & 2.21 & 0.33 & $\mathrm{i} \neq>$ cpi \\
\hline I & 2 & $2+1$ & 10.30 & $6 e-3$ & $\mathbf{I} \rightarrow \mathbf{c p i}$ \\
\hline Y & 2 & $2+1$ & 4.46 & 0.11 & $\mathrm{Y} \neq>$ cpi \\
\hline
\end{tabular}


Table 5: Simple Granger Causality Test Results (i, I, Y, cpi)

\begin{tabular}{|c|c|c|c|}
\hline $\begin{array}{c}\mathrm{H}_{0} \text { (causality } \\
\text { does not exist) }\end{array}$ & F statistic & Prob. & $\begin{array}{c}\text { Direction of } \\
\text { Causality }\end{array}$ \\
\hline \multicolumn{4}{|l|}{$d(i)$ interest rate } \\
\hline from $\mathrm{I}$ to $\mathrm{i}$ & 1.27 & 0.29 & $\mathrm{I} \neq>\mathrm{i}$ \\
\hline from $Y$ to i & 1.18 & 0.31 & $Y \neq>i$ \\
\hline from cpi to i & 8.06 & $6 e-4$ & cpi $\rightarrow \mathbf{i}$ \\
\hline \multicolumn{4}{|l|}{$\begin{array}{l}\text { (I) fixed capital } \\
\text { investment }\end{array}$} \\
\hline from i to I & 1.18 & 0.31 & $i \neq>I$ \\
\hline from $Y$ to I & 14.56 & $4 e-6$ & $\mathbf{Y} \rightarrow \mathbf{I}$ \\
\hline from cpi to I & 1.77 & 0.18 & cpi $\neq>\mathrm{I}$ \\
\hline \multicolumn{4}{|l|}{$(Y)$ income } \\
\hline from $i$ to $Y$ & 0.10 & 0.90 & $\mathrm{i} \neq>\mathrm{Y}$ \\
\hline from I to $\mathrm{Y}$ & 0.05 & 0.95 & $\mathrm{I} \neq>\mathrm{Y}$ \\
\hline from cpi to $Y$ & 2.98 & 0.06 & cpi $\neq>Y$ \\
\hline \multicolumn{4}{|l|}{ (cpi) inflation } \\
\hline from i to cpi & 2.02 & 0.14 & $\mathrm{i} \neq>\mathrm{cpi}$ \\
\hline from I to cpi & 1.91 & 0.16 & $\mathrm{I} \neq>$ cpi \\
\hline from $Y$ to cpi & 3.19 & 0.05 & $\mathbf{Y} \rightarrow \mathbf{c p i}$ \\
\hline
\end{tabular}




\section{Figure 3: Toda-Yamamoto}

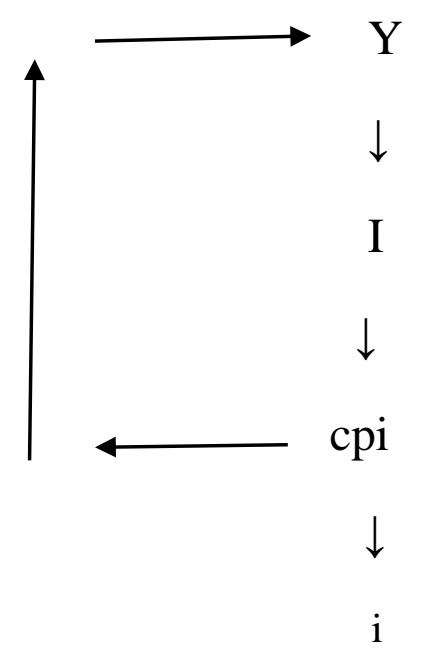

\section{Figure 4: Granger Causality}

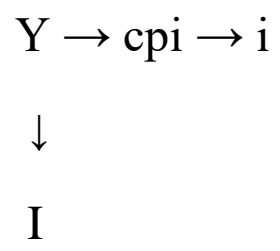

Similar to the TY in figure (1) with industry production, causality runs in reverse order from $\mathrm{Y}$ and investment to cpi and from cpi to interest rate directly. This time there is also direct effect from cpi to $Y$. Income effects cpi indirectly via investments. Results of simple Granger test reveal causality at the five percent significance level from $Y$ to cpi and from there towards the interest rate; as well as from $Y$ to investment. Once again findings together imply causality running from total demand (income and investment) to cpi. Only by then monetary authority intervenes by the interest rate tool, to adjust demand and inflation. There is lack of evidence for the interest rate channel in the Keynesian sense.

Overall relevance of dynamics (both with industrial production and income) point at demand pull inflation in the economy. Real sector measures of investment incentive packages during 2009, 2012 and 2016 with the tax, labor cost, land donation, special interest rate, energy incentives seem to have had important effects on real economic aggragates, as well as consumer 
credit policies. Credit and asset price channels of the monetary transmission mechanism ${ }^{5}$ may have resulted in increased investment and consumption which needs to be proved by research conducted on the matter. The

\section{Conclusions}

It is important to know how the monetary policy measures via money supply, interest rates, reserves etc. work to affect real economic aggregates of income, employment etc. by the monetary transmission mechanism. This paper has examined causality of the interest rate channel via Toda-Yamamoto Methodology and Granger Causality.

Causality is analyzed for two separate sets of variables: first with (i), (I), (ind), (cpi) and then with (i), (I), (Y), (cpi). Results reveal causality goes like ind $\rightarrow \mathrm{I} \rightarrow$ cpi $\rightarrow \mathrm{i}$ as per TY method, whereas it is cpi $\leftrightarrow \mathrm{i}$ and ind $\leftrightarrow \mathrm{I}$ as per Granger causality. With the (Y) variable it is similarly $\mathrm{Y} \rightarrow \mathrm{I} \rightarrow \mathrm{cpi} \rightarrow \mathrm{i}$; and with Granger it is $\mathrm{Y} \rightarrow \mathrm{cpi} \rightarrow \mathrm{i}$. It is observed that monetary policy affects industrial production/income reflecting on investments which raising (lowering) the economic activity, creates inflationary (deflationary) pressures. Interest rates are used only then to curb (boost) demand and adjust prices. There is no interest rate channel in the traditional/New Keynesian sense so it is possible that real sector measures brought in by the incentive packages may have affected economic dynamics through credit and financial assets channels which need to be investigated.

Previous empirical studies have revealed that interest rate channel has been operative during the 1990s-2000s, becoming even more effective during post 2001 crises years of lower and stable inflation. Yet the mentioned studies only extend up until the year 2008, (only Saraç and Uçan up to 2011) and do not cover the new and exceptional policy period of post 2010 with extended targets and tools. Results reveal that, contrary to previous findings of the period until 2008, interest rate channel has not worked in the Keynesian sense during the 2011-2018 period of the inflation targeting regime. The multitude of policy rates may have blocked the signals of

\footnotetext{
${ }^{5}$ There is no evidence for the exchange rate channel that by lowering interest rates, net exports having risen (and vice versa). Rather capital inflows have affected exchange rates by liquidity conditions.
} 
the mechanism. Post 2018 period involves further changes in policy measures which should also be subject matter of future studies.

\section{References}

Aktaş, Z. et al. (2009). Transmission of Monetary Policy in Turkey: Effects of Monetary Policy on Financial Markets. İktisat Işsletme ve Finans. 24(278) 2009 pp. 9-24.

Alimi S.R., Ofonyelu, C.C. (2013). Toda-Yamamoto Causality Test Between Money Market Interest Rate and Expected Inflation: The Fisher Hypothesis Revisited. European Scientific Journal. March 2013 ed. Vol. 9, No.7.

Arestis, P., Sawyer, M. (2003). Can Monetary Policy Affect the Real Economy: The Dubious Effectiveness of Interest Rate Policy? The Levy Economics Institute of Bard College, Public Policy Brief, No. 71.

Başçı, E., Özel, Ö. and Sarıkaya, Ç. (2007).The Monetary Transmission Mechanism in Turkey: New Developments. Research and Monetary Policy Department WP. No. 07/04.

Bernanke, B. (1988). Monetary Policy Transmission: Through Money or Credit? Business Review. November/December 1988.

Bernanke, B.S., Gertler, M. (1995). Inside the Black Box: The Credit Channel of Monetary Policy Transmission. Journal of Economic Perspectives. Vol.9, No.4- Fall 1995-pp. 27 48.

Berument, H., Froyen, R.T. (2006). Monetary Policy and Long Term US Interest Rates. Journal of Macroeconomics. 28 (2006) 737-751

Bhuiyan, R., Lucas, R.F. (2007). Real and Nominal Effects of Monetary Policy Shocks. Canadian Journal of Economics. 40 (2) 679-702.

Butzen, P., Fuss, C., Philip, V. (2001), The Interest Rate and Credit Channels in Belgium: An Investigation with Micro-Level Firm Data. European Central Bank Working Paper 17.

Büyükakın, F., Bozkurt, H. and Cengiz, V. (2009). Analysis of the Interest Rate Channel of Monetary Transmission with Granger Causality and Toda-Yamamota Method in Turkey. Erciyes Üniversitesi İktisadi ve İdari Bilimler Fakültesi Dergisi. Sayı: 33, Temmuz-Aralık 2009, 101-118.

Chirink, R.S., Kalckreuth, U.V. (2003). On the German Transmission Mechanism: Interest Rate and Credit Channels for Investment Spending. CES ifo WP No. 838: 1-43. 
Coffinet, J. (2005). The Single Monetary Policy and the Interest Rate Channel in France and the Euro Area. Banque de France Bulletin Digest. 139 july, pp. 7-16.

Demary, M. (2010). The Interplay between Output, Inflation, Interest Rates and HousePrices:

International Evidence, Journal of Property Research. 27(1), 1-17.

Dritsaki, C. (2017). Toda-Yamamoto Causality Test Between Inflation and Nominal Interest Rates: Evidence from Three Countries of Europe. International Journal of Economics and Financial Issues. 7(6), 120-129.

Engle, R.,F., Granger, C.W.J. (1987). Cointegration and Error Correction: Representation, Estimation and Testing. Econometrica. 55, pp. 391-407.

Erdoğan, S., Yıldırım, D.Ç (2010). Is There Interest Rate Channel for Monetary Policy in Turkey. METU Studies in Development. Vol.37 No.3

Gujarati, D.,N., (2006). Essential of Econometrics. 3rd Edition, MacGraw Hill.

Hubbard, R.G. (1995). Is There a Credit Channel for Monetary Policy? Federal Reserve Bank of Saint Louis. May/June 1995.

İnal, D.G. (2006). The Effect of Interest Rate Decisions on the Long-Term Interest Rate in Turkey. TCMB, Specialist Thesis.

Johansen, S. (1991). Estimation and Hypothesis Testing of Cointegration Vectors in Gaussian Vector Autoregressive Models. Econometrica. 59, pp. 1551-1580.

Johansen, S., Juselius, K. (1990). Maximum Likelihood Estimation and Inference on Cointegration-With Aplications for the Demand for Money. Oxford Bulletin of Economics and Statistics. 52, 2: pp. 169-210.

Kara, H., et al. (2007): "Estimating the Output Gap in a Changing Economy." Southern Economic Journal. 74 (1)

Keyder, N., Ertunga, D.İ. (2012). Para, Teori, Politika, Uygulama. Ankara: Seçkin Yayıncılık ve Dağıtım.

Mehrotra, A.N. (2007). Exchange and interest Rate Channels in a Deflationary era: Evidence from Japan Hong Kong and China. Journal of Comparative Economics. 35 pp: 188-210

Mishkin, F.S. (2004). Economics of Money, Banking and the Financial Markets. USA: Addison and Wesley.

Mishkin, F.S. (1995). Symposium on the Monetary Transmission Mechanism. Journal of Economic Perspectives. Vol.9, No.4- Fall 1995-pp. 3-10. 
Mojon, B., Peersman, G. (2001). A VAR Description of the Effects of Monetary Policy in the Individual Countries of the Euro Area. ECB Working Paper. No.92 December, 2001.

Özatay, F. (2011). The New Monetary Policy of the Central Bank: Two Targets, Two Intermediate Targets, Three Tools. Iktisat Işletme ve Finans. 26 (302) 2011: 27-43.

Peersman, Gent. (2001). The Transmission of Monetary Policy in the Euro Area: Implications for the European Central Bank. PhD Thesis, Universiteit Gent, Dept of Economics and Business Administration.

Petursson, T.G. (2001). The transmission Mechanism of Monetary Policy: Analysing the Financial Market Pass-Through. Central Bank of Iceland WP. No.14.

Press Statement About Operational Framework of the Monetary Policy. < https://www.tcmb.gov.tr/wps/wcm/connect/tr/tcmb+tr/main+menu/duyurular/basin/201 8/duy2018-21> Review. 6 (3): 6-13.

Reyes, L.O. (2002). A VAR analysis of the Monetary Transmission Mechanism in the USA.

Saraç, B.S., Uçan, O. (2013). The Interest Rate Channel in Turkey: An Investigation with Kalman Filter Approach. International Journal of Economics and Financial Issues. Vol.3, No.4, 2013, pp.874-884.

Sellon, G.H. (2002), The Changing U.S. Financial System: Some Implications for the Monetary Transmission Mechanism. Federal Reserve Bank of Kansas Economic Review, 1, 5-35. State Institute of Statistics Database. <http://www.tuik.gov.tr>, 2019, december.

Taylor, J.B. (2000). The Monetary Transmission Mechanism and the Evaluation of Monetary Policy Rules. Working Papers Central Bank of Chile 87.

Taylor, J.B. (1995). The Monetary Transmission Mechanism: An Empirical Framework. Journal of Economic Perspectives. Vol.9, No.4- Fall 1995-pp. 11-26.

Toda, H.Y., Yamamoto, T. (1995). Statistical Inference in Vector Autoregressions with Possibly Integrated Processes. Journal of Econometrics. 66, pp.225-250.

Tunalı, H., Yalçınkaya, Y. (2017). International Journal of Economic Studies. Granger Causality Analysis Between US Dollar, Inflation and Weighted Average Cost of the CBRT Funding. International Journal of Economic Studies. Sept. 2017, Vol.3, Iss: 3.

Turkish Central Bank Database. <http://www.tcmb.gov.tr>, 2019, december.

Üçer, M. (2011). Observations on Recent Monetary Policy Measures. Íktisat Işsletme ve Finans. 26 (302) May, 2011. 
Weber, A. (2006). The Role of Interest Rates in Theory and Practice: How Useful Is the Concept of the Natural Real Rate of Interest for Monetary Policy? Inaugural G.L.S. Shackle Biennial Memorial Lecture, St. Edmund's College, Cambridge,March.

Woodford, M. (2003). Interest and Prices: Foundations of a Theory of Monetary Policy. Princeton: Princeton University Press.

Yue, Y., Zhou, S. (2007). Empirical Analysis of Monetary Policy Transmission. Chinese Business 


\section{APPENDIX I.}

\section{VAR Lag Order Selection Criteria - I}

Endogenous variables: D(R_SA) CPI1_SA IND09N INV1_SA

Exogenous variables: $\mathrm{C}$

Date: $02 / 03 / 20$ Time: $21: 30$

Sample: 2011M01 2018M06

Included observations: 85

\begin{tabular}{ccccccc}
\hline \hline Lag & LogL & LR & FPE & AIC & SC & HQ \\
\hline \hline 0 & NA & NA & 958.3267 & 18.21669 & 18.33164 & 18.26293 \\
1 & NA & 475.5620 & 3.660774 & 12.64864 & $13.22338^{*}$ & 12.87982 \\
2 & NA & 62.60032 & $2.346910^{*}$ & $12.20142^{*}$ & 13.23596 & $12.61754^{*}$ \\
3 & NA & $26.86705^{*}$ & 2.370038 & 12.20474 & 13.69907 & 12.80580 \\
4 & NA & 14.29978 & 2.832812 & 12.37092 & 14.32504 & 13.15692 \\
\hline \hline
\end{tabular}

* indicates lag order selected by the criterion

LR: sequential modified LR test statistic (each test at $5 \%$ level)

FPE: Final prediction error

AIC: Akaike information criterion

SC: Schwarz information criterion

HQ: Hannan-Quinn information criterion

\section{VAR Lag Order Selection Criteria - II}

Endogenous variables: D(R_SA) CPI1_SA GDP1_SA INV1_SA

Exogenous variables: $\mathrm{C}$

Date: 02/03/20 Time: 21:41

Sample: 2011M01 2018M06

Included observations: 85

\begin{tabular}{ccccccc}
\hline \hline Lag & LogL & LR & FPE & AIC & SC & HQ \\
\hline \hline 0 & NA & NA & 271.9030 & 16.95695 & 17.07190 & 17.00318 \\
1 & NA & 669.7658 & 0.091665 & 8.961347 & 9.536089 & 9.192524 \\
2 & NA & 80.92150 & $0.046178^{*}$ & $8.273061^{*}$ & $9.307596^{*}$ & $8.689180^{*}$ \\
3 & NA & 15.39895 & 0.054685 & 8.435657 & 9.929985 & 9.036718 \\
4 & NA & $28.70218^{*}$ & 0.052886 & 8.390037 & 10.34416 & 9.176039 \\
\hline \hline
\end{tabular}

* indicates lag order selected by the criterion

LR: sequential modified LR test statistic (each test at 5\% level)

FPE: Final prediction error

AIC: Akaike information criterion

SC: Schwarz information criterion

$H Q$ : Hannan-Quinn information criterion 